\section{Imigração e contextos culturais}

\author{
Szilvia Simai* \\ Rosana Baeninger**
}

\begin{abstract}
MAZZA, Débora; VON SIMSON, Olga (Orgs.). Mobilidade humana e a diversidade sócio-cultural. São Paulo: Centro de Memória/Unicamp; Paco Editorial, 2011. ISBN: 978-85-64367-04-3.
\end{abstract}

A proposta principal do livro, produzido por estudiosos que abordam questões relativas à cultura e suas inter-relações com a mobilidade da população, está assentada na importância das migrações, tanto em nível local quanto global, para a (trans)formação de culturas. A obra evidencia que a própria cultura, por sua vez, também está "migrante", avançando no estudo da multiplicidade de contextos culturais e a imigração. Os autores utilizam uma variedade de situações, disciplinas e metodologias, contemplando aspectos relevantes da relação migração e cultura, tais como as trajetórias do deslocamento, as fronteiras, as identidades, os contatos transnacionais, a memória cultural, a transmissão da identidade pelas gerações, as questões da diferença cultural e hibridismo, as histórias orais da migração e a função das novas tecnologias e seu papel entre culturas.

A coletânea tem duas partes principais. A primeira mostra detalhadamente como o estudo da migração envolve inúmeras possibilidades de rotas disciplinares e de metodologias de pesquisa. Contempla diversos campos disciplinares nos estudos sobre imigração internacional e inova na inter-relação entre ciências sociais e artes. Nessa perspectiva, os autores apresentam uma rica coleção interdisciplinar sobre a mobilidade humana. Alguns artigos usam uma abordagem das ciências sociais, mostrando elementos de estudos de mídia, de sociologia e de psicologia social. O lado mais forte do livro é a inclusão de campos pouco discutidos, como a análise literária de Albert Camus em uma conceituação filosófica da estranheza e alteridade por meio de análise semiótica e pós-colonial. Destaque-se também a voz que é dada às crianças como protagonistas de suas vidas, o que demonstra a capacidade do livro em trazer elementos inovadores e sofisticados para análise de estudos imigratórios. O livro apresenta, ainda, o uso do cinema como uma forma de retratar experiências migratórias, bem como as novas formas de internacionalizações e suas imigrações, envolvendo trajetórias migratórias acadêmicas, o que enriquece nossa compreensão acerca das mobilidades contemporâneas como experiências vividas.

A segunda parte focaliza e reconstrói movimentos migratórios internacionais para o Brasil, destacando a importância da muIher nesses contextos imigratórios. Italianas, portuguesas, alemãs, japonesas e latino-americanas compõem o universo social das migrações no Brasil. Nesse aspecto, o livro é oportuno e inovador, ao dar visibilidade às mulheres imigrantes e sua importância nas constituições dos fenômenos migratórios históricos e contemporâneos.

A presença da mulher imigrante é retratada de maneira exemplar, desde as vivências familiares nas ex-colônias portuguesas até as mulheres latinas hoje na cidade de São Paulo. A leitura da coletânea permite percorrer pela participação da mulher imigrante por diferentes olhares: na música, na família imigrante, nas gerações de imigrantes, nas relações de gênero, na educação, na formação de identidades dessas mulheres; aspectos que refletem a dinamização do processo cultural.

O livro aponta a complexidade do fenômeno imigratório e seus contextos cul-

\footnotetext{
* Doutora em Psicologia Social; Núcleo de Estudos de População/Universidade Estadual de Campinas.

** Doutora em Ciências Sociais; Departamento de Demografia e Núcleo de Estudos de População/Universidade Estadual de Campinas.
} 
turais, ressaltando os desafios teórico-metodológicos, de um lado, e retratando as dificuldades vividas pelos imigrantes e pelas imigrantes nos novos espaços sociais, de outro. Do ponto de vista dos projetos migratórios, esses desafios impostos aos imigrantes tornam-se parte de processos identitários e da construção social da própria imigração e dos indivíduos nela envolvidos.

Recebido para publicação em 20/12/2011

Aceito para publicação em 05/03/2012 